\title{
CORRELATION BETWEEN ANTRHOPOMETRIC INDICATORS AND BLOOD PRESSURE IN ADOLESCENTS
}

\author{
Aline Viana de Oliveira ${ }^{1}$, Ana Cristina Pereira de Jesus Costa², Livia Maia Pascoal ${ }^{3}$, Leonardo Hunaldo dos \\ Santos ${ }^{4}$ Emilia Soares Chaves 5 , Márcio Flávio Moura de Araújo ${ }^{6}$
}

${ }^{1}$ RN. Family Health Strategy nurse. São Luiz, Maranhão, Brazil. E-mail: alynneolliveira@hotmail.com

${ }^{2}$ Master of Nursing. Professor in the Nursing Undergraduate Program, Universidade Federal do Maranhão (UFMA). São Luiz, Maranhão, Brazil. E-mail: anacristina_itz@hotmail.com

${ }^{3}$ Master of Nursing. Professor in the UFMA Nursing Undergraduate Program. São Luiz, Maranhão, Brazil. E-mail: livia_mp@ hotmail.com

${ }^{4}$ Doctor of Zootechnics. Professor in the UFMA Nursing Undergraduate Program. São Luiz, Maranhão, Brazil. E-mail: leohunaldo@yahoo.com.br

${ }^{5}$ Doctor of Nursing. Professor in the Nursing Undergraduate Program, Universidade da Integração Internacional da Lusofonia Afro-Brasileira (UNILAB). Fortaleza, Ceará, Brazil. E-mail: emilia@unilab.edu.br

${ }^{6}$ Doctor of Nursing. Professor in the UNILAB Nursing Undergraduate Program. Fortaleza, Ceará, Brazil. E-mail: marciofma@ unilab.edu.br

\begin{abstract}
The objective of the present study was to analyze the correlation between anthropometric indicators and blood pressure of adolescents from Imperatriz, state of Maranhão, Brazil. It is a quantitative cross-sectional study, developed between September and November of 2012 with 218 students. We used a questionnaire to collect data regarding identification, anthropometrics, and systolic and diastolic blood pressure. Considering blood pressure, we found that $4.6 \%, 2.4 \%$ and $1.3 \%$ of the sample were included in the borderline, stage 1 and stage 2 hypertension categories, respectively. Among female participants, body adiposity index and skinfold presented higher mean values than those of their male counterparts. Furthermore, we observed a positive correlation between systolic blood pressure and height $(\mathrm{r}=0.18)$, weight $(\mathrm{r}=0.20)$ and waist circumference $(\mathrm{r}=0.17)$, and a negative correlation between diastolic blood pressure and body adiposity index $(\mathrm{r}=-0.18)$. The measures of neck and waist circumference were the only anthropometric measures with positive and simultaneous correlations with systolic blood pressure for both genders.
\end{abstract}

DESCRIPTORS: Arterial pressure. Adolescent. School health.

\section{CORRELAÇÃO ENTRE INDICADORES ANTROPOMÉTRICOS E PRESSÃO ARTERIAL DE ADOLESCENTES}

RESUMO: O objetivo deste estudo foi analisar a correlação entre indicadores antropométricos e pressão arterial de adolescentes de Imperatriz-MA. Trata-se de estudo quantitativo do tipo transversal, desenvolvido entre setembro e novembro de 2012 com 218 estudantes. O questionário utilizado contemplou dados de identificação, antropométricos e pressão arterial sistólica e diastólica. Quanto aos valores de pressão arterial, verificou-se que 4,6\%, 2,4\% e 1,3\% da amostra estavam inseridos na categoria limítrofe, hipertensão em estágio I e II, respectivamente. Entre o sexo feminino, o índice de adiposidade central e todas as pregas cutâneas apresentaram valores médios superiores ao masculino e, ainda, constatou-se correlação positiva entre pressão arterial sistólica e altura $(r=0,18)$, peso $(r=0,20)$ e circunferência da cintura $(r=0,17)$; negativa entre pressão arterial diastólica e índice de adiposidade central $(r=-0,18)$. A medida da circunferência do pescoço e da cintura foi a única medida antropométrica com correlação positiva e simultânea com pressão arterial sistólica em ambos os sexos.

DESCRITORES: Pressão arterial. Adolescente. Saúde escolar.

\section{CORRELACIÓN ENTRE LOS INDICADORES ANTROPOMÉTRICOS Y PRESIÓN ARTERIAL DE LOS ADOLESCENTES}

RESUMEN: El objetivo de este estudio fue analizar la correlación entre la presión antropométrico y sangre de los adolescentes de Imperatriz-MA. Se trata de un estudio transversal, realizado entre septiembre y noviembre de 2012 con 218 estudiantes. El cuestionario incluía datos de identificación, antropométricas y de presión arterial sistólica y diastólica. En el análisis de las pruebas de correlación de Pearson y de Spearman utilizado bajo criterios preestablecidos. Sólo el 8,3\% de la muestra tenía cifras de presión arterial fuera del rango normal, siendo un 4,6\%, 2,4\% y 1,3\% en el límite de la categoría hipertensión en estadio I y II, respectivamente. En las mujeres la tasa de obesidad central y pliegues cutáneos mostraron los mayores valores medios que los hombres. En las niñas hay una correlación positiva entre la presión arterial sistólica y la altura $(\mathrm{r}=0,18)$, el peso $(\mathrm{r}=0,20)$ y la circunferencia de la cintura $(\mathrm{r}=0,17)$; correlación negativa entre la presión arterial diastólica y el índice de adiposidad central $(\mathrm{r}=-0,18)$. Una sola medida antropométrica que se correlaciona positivamente con la presión arterial sistólica y simultánea en ambos sexos es la medida de la circunferencia del cuello y la cintura.

DESCRIPTORES: Presión arterial. Adolescente. Salud escolar. 


\section{INTRODUCTION}

Systemic arterial hypertension (SAH) is a multifactorial clinical condition chraacterized by high and sustained levels of blood pressure (BP). It is frequently associated with functional and/or structural alterations of target organs and metabolic alterations, with the subsequent increase of risk for fatal and non-fatal cardiovascular events. Therefore, it is a relevant public health problem. High blood pressure (HBP) in the initial stages of life has demonstrated strong correlation with $\mathrm{SAH}$ in adulthood. Evidence indicates that HBP affects about 3.5 million Brazilian children and adolescents, and if measures are not taken, these young people will be subject to a variety of future cardiovascular problems. ${ }^{1-2}$

Among the several risk indicators that contribute to developing SAH in adolescents, the most common are high initial BP rates, family history, obesity, sedentarism, smoking and alcoholism. ${ }^{2}$ On this regard, it has been observed that adolescents have increased their consumption of industrialized food, eating outside the home and substituting traditional meals for high salt, fat and sugar snacks. The opposite is true with respect to the consumption of fruit, vegetables, legumes and whole grains. ${ }^{3}$

Adolescence is a critical phase for the accumulation of adipose tissue for both genders, leading to a predisposition to obesity and its comorbidities, such as SAH. It is estimated that approximately $30 \%$ of overweight/obese Brazilian children and adolescents have SAH. A longitudinal study developed with Brazilian adolescents during 25 years indicated a greater prevalence of excess weight among individuals who maintained high BP throughout the study. ${ }^{4}$ We also consulted other authors who emphasize that excess weight is one of the most important factors related to this cardiovascular disease among younger people in the national and global panorama. ${ }^{5-7}$

The effectiveness of HBP screening in children and adolescents is not clear. According to recent publications, the variability of this hemodynamic parameter is high, decreasing its predictive power. ${ }^{6-7}$ On the other hand, many authors recommend monitoring altered blood pressure cases among the youth population through the use of anthropometric indicators. ${ }^{5,8-10}$

Although there is no consensus regarding the best anthropometric predictor of elevated blood pressure in the child and adolescent population, it is important to use simple, practical and economic methods for evaluating cardiovascular risk. Thus, such methods are essential in the context of clinical practice, in the school's daily routine and in the field of epidemiological research, for they allow the early detection of children and adolescents at risk for developing HBP due to excessive adiposity. ${ }^{4,10}$

The body adiposity index (BAI) is the reference point for classifying weight status as normal, overweight, obesity or morbid obesity. It is also a more reliable alternative for quantifying body fat. In contrast, the body mass index (BMI) represents robustness more than adiposity, for muscular and obese individuals can present the same BMI. In fact, some researchers recommend that preference be given to the use of anthropometric measures that represent the distribution of body fat instead of the BMI, to establish a significant association between excess weight and high BP levels in children and adolescents. ${ }^{11}$

Waist circumference (WC) is the main indicator of abdominal concentration of fat and is commonly associated with the same risk factors related to obesity. Among these, we have the measurement of skinfolds and, more recently, the waist-stature ratio, which are being investigating regarding their accuracy in predicting the risk of higher blood pressure. ${ }^{10,12}$ However, further research is necessary to clarify the relation of $\mathrm{BP}$ with the triceps skinfold and waist-stature ratio. Thus, such measurements constitute important methods for diagnosing overweight/obesity and central obesity in epidemiological studies and in clinical practice, due to their simple-to-use, precise and reproducible nature. ${ }^{4,12}$

Another important measurement is the neck circumference (NC), which has also been investigated as a screening instrument for individuals with excess body fat. Furthermore, it has been correlated to several anthropometric measurements regarding fat localization, as well as to cardiovascular risk factors. ${ }^{12}$

It is necessary to conduct studies aimed at identifying anthropometric indicators that help track the risk for juvenile hypertension and overweight according to Brazilian standards, especially those related to anthropometric indicators, waist-stature ratio, skinfolds and waist circumference. Considering the divergence and scarcity of Brazilian publications associating anthropometric indicators with risk for hypertension among children and adolescents, the objective of 
the present study was to analyze the correlation between anthropometric indicators and blood pressure of adolescents in the city of Imperatriz, state of Maranhão, Brazil.

\section{METHOD}

This is a quantitative cross-sectional study ${ }^{13}$ conducted between September and November of 2012 in a public school of the state educational system of the city of Imperatriz, Maranhão, Brazil. The municipality of Imperatriz has a population of 234,547 inhabitants, is located in the southeast of Maranhão and is a regional reference for its educational and health services.

As in other Brazilian municipalities, the Imperatriz municipal educational system consists of municipal, state and private schools. There are 20 thousand students enrolled in the public school system divided among 30 schools, seven thousand in elementary schools and 13 thousand in high schools.

For the purposes of data collection, we chose a state institution that participates in the following university outreach program: "Adolescence: its nature and conflicts," offered by the Federal University of Maranhão, with a diverse student body from different neighborhoods of Imperatriz.

Before entering the study, all participants presented the free and informed consent form duly signed by parents/legal guardians for those under 18 years. The study respected all ethical and legal principles regarding human research in Brazil, such as providing information about the study's risks, benefits, and participant's anonymity. The Research Ethics Committee of the Federal University of Ceará approved this study, under protocol n. 253/10.

We selected participants by convenience, according to the following inclusion criteria: being an adolescent, that is, aged between 10 and 19 years, according to the definition provided by the World Health Organization; ${ }^{14}$ being a high school student; both genders; studying in the morning or afternoon period and not presenting any anatomical alteration that would interfere in the measurement of anthropometric data. This school had 379 regularly enrolled students with the characteristics mentioned above. Of these, 219 agreed to participate, 160 declined and one pregnant student was removed from the study. Thus, our sample consisted of 218 subjects.
Data were collected between September and November of 2012, by five nursing academics who, in August 2012, participated in a 12-hour training session in order to standardize measurement procedures and data collection. It was also an opportunity for acquiring familiarity with the study's instruments to avoid possible bias in data collection.

The instrument for data collection was divided into three parts: identification (age, sex and grade level), anthropometric data and blood pressure data. The measured anthropometric data were height, weight, waist circumference (WC), hip circumference (HC), neck circumference (NC), waist-hip ratio (WHR) and waist-stature ratio (WSR). We also measured the following skinfolds: triceps (TSF), biceps (BSF), chest (CSF), abdominal (ASF) and iliac crest (ICSF). Furthermore, we calculated the body adiposity index (BAI), and took systolic (SBP) and diastolic (DBP) blood pressure measures.

For weight measurement, subjects were barefoot and wearing light clothing and we used a portable Techline ${ }^{\circledR}$ digital scale with a $0.1 \mathrm{~kg}$ precision. Height was measured using a stadiometer attached to a mechanical anthropometric scale with a $0.5 \mathrm{~cm}$ sensitivity. In order to guarantee the precision of height measurements, participants were instructed to stand upright and immobile, open hands on thighs and head adjusted to the Frankfurt horizontal. ${ }^{15}$

We measured $\mathrm{WC}, \mathrm{HC}$ and $\mathrm{NC}$ using an inextensible and inelastic measuring tape, according to the correct technique for measuring circumferences, including being careful to avoid compressing adipose skin tissue and positioning the tape correctly in order to delimitate the mid-point of the particular circumference..$^{15}$ The results for WC values were stratified into normal and high. For participants aged 17 or under, the cutoff points were analyzed according to Taylor's criteria, which takes into account the adolescent's age and sex. ${ }^{15}$ For the 25 participants aged 18 and older, we considered values $\geq 94 \mathrm{~cm}$ as high for males and $\geq 80 \mathrm{~cm}$ for females. ${ }^{16}$ Hip circumference was measured around the most prominent region of the gluteus. ${ }^{15}$

For determining NC, we instructed participants to stand still, with their head in the Frankfurt horizontal, looking straight ahead. In the present study, male adolescents were classified as having altered NC when presenting values $\geq 39 \mathrm{~cm}$, and 
not altered for values $<39 \mathrm{~cm}$. For women, NC was considered altered for values $\geq 35 \mathrm{~cm}$ and not altered for values $<35 \mathrm{~cm} .{ }^{17}$

By dividing $\mathrm{WC}$ by $\mathrm{HC}$, we obtained the HWR, which was stratified into low, moderate, high and very high. The values obtained were interpreted according to the Canadian Standardized Test of Fitness, specific for adolescents. ${ }^{17}$ The WSR was obtained by dividing WC by height in centimeters, and we established 0.50 as the limit for normal WSR value. ${ }^{18}$

Skinfold thickness was measured with a high-precision Sanny ${ }^{\circledR}$ research-quality caliper with a $0.1 \mathrm{~mm}$ sensitivity and at constant pressure, calipered by the Brazilian Calibration Network. We took three measurements for each skinfold and then calculated their arithmetical mean to use as data. Skinfold measurements occurred in the following order: triceps (TSF), biceps (BSF), chest (CSF), abdominal (ASF) and iliac crest (ICSF). In order to guarantee measurement accuracy and reliability, skinfolds were measured with participants in standing position, arms relaxed alongside their body. Calipers were correctly positioned according to the specific literature. ${ }^{15}$

We obtained BAI by dividing the WC $(\mathrm{cm})$ by height $(\mathrm{m})$, multiplied by the square root of height. From this result, we subtracted 18 and established the following stratification for men: normal weight (8-20), overweight (21-25) and obesity (>25). For women, these items were scored as 21-32, 33-38 and $>38$, respectively.

Blood pressure was measured using an automatic Techline MG 150f ${ }^{\circledR}$ digital arm sphigmomanometer, with an easily adjustable nylon cuff over the main artery, $2-3 \mathrm{~cm}$ above the cubital fossa. The device's range of measurement and maximum error were $40-250 \mathrm{mmHg}$ and $\pm 3 \mathrm{mmHg}$, respectively. The instrument is registered at the Brazilian Health Surveillance Agency and possesses a seal of quality from the National Institute of Metrology, Quality and Technology. Measurements were taken three times, with a one-minute interval between each take. The mean of the last two measurements was established as the individual's blood pressure. Before verifying blood pressure, we conducted the care procedures recommended by the Brazilian Society of Hypertension in order to guarantee the reliability of the measurements obtained. ${ }^{1}$
Results of BP measurements were analyzed considering the classification for children and adolescents based on age group, height and sex. Thus, adolescents with SBP and DBP lower than values corresponding to the $90^{\text {th }}$ percentile were interpreted as normal. Those with SBP and/or DBP equal to or greater than the $90^{\text {th }}$ percentile, and lower than the $95^{\text {th }}$ percentile were classified as pre-hypertensive. Adolescents who reached SBP and DBP values equal to or greater than the $95^{\text {th }}$ percentile were classified as presenting high blood pressure, supposedly hypertensive. ${ }^{1}$

Three team members typed the collected information and, after comparison, it was stored in a data bank on a Microsoft Excel 2007 spreadsheet. We conducted data analysis with the help of the Statistical Analysis System software. The association between SBP and DBP measurements and anthropometric measurements (height, weight, BAI, WC, HC, WHR, WSR, NC, BSF, TSF, CSF, ASF, and ICSF) was investigated through Pearson's correlation coefficient for variables that presented normal distribution and homogeneity of variance. For variables with non-normal distribution and/ or heterogeneity of variance, we used Spearman's correlation coefficient.

For all the analyzed variables, normality was measured through the Shapiro-Wilk test, and homogeneity, through the Bartlett's test, both at a $5 \%$ significance level. These assumptions were accepted for the SBP, DBP, height, weight, BAI, WC, $\mathrm{HC}$ and WHR variables, which presented normal distribution and homogeneity of variance. On the other hand, WSR, NC, TSF, BSF, CSF, ASF and ICSF presented non-normal distribution. These associations were investigated according to the specificities of each sex.

\section{RESULTS}

The distribution of the adolescents indicated a numerical superiority of the female sex (59.8\%), mean age 16.3 years (SD \pm 1.1 ). Regarding age, there was a prevalence of 16 to 17 years, corresponding to $60.6 \%$ of the total sample. Concerning high school grade, $48.6 \%$ were in their first year, $18.2 \%$ in the second and $32.7 \%$ in the third and final year, respectively. 
Table 1 - Mean values and standard deviation of the measurements of adolescents according to sex. Imperatriz, Maranhão, Brazil, 2012 (n=218)

\begin{tabular}{lcccc}
\hline \multirow{2}{*}{ Variables } & \multicolumn{2}{c}{ Male } & \multicolumn{2}{c}{ Female } \\
& Mean & Standard deviation & Mean & Standard deviation \\
\hline SBP $(\mathrm{mmHg})$ & 112.35 & 12.41 & 101.57 & 10.45 \\
DBP $(\mathrm{mmHg})$ & 63.64 & 9.01 & 62.56 & 7.96 \\
Height $(\mathrm{m})$ & 1.68 & 0.07 & 1.56 & 0.06 \\
Weight $(\mathrm{kg})$ & 59.05 & 9.08 & 50.87 & 8.17 \\
BAI & 23.56 & 2.89 & 28.61 & 3.69 \\
WC $(\mathrm{cm})$ & 72.54 & 5.46 & 69.47 & 6.47 \\
HC $(\mathrm{cm})$ & 60.37 & 6.20 & 90.69 & 6.45 \\
WHR & 0.80 & 0.04 & 0.76 & 0.05 \\
WSR & 0.43 & 0.03 & 0.44 & 0.04 \\
NC $(\mathrm{cm})$ & 35.29 & 2.13 & 31.43 & 1.83 \\
TSF $(\mathrm{mm})$ & 9.90 & 3.77 & 15.76 & 4.13 \\
BSF $(\mathrm{mm})$ & 6.42 & 2.20 & 10.05 & 2.83 \\
CSF $(\mathrm{mm})$ & 7.29 & 2.10 & 10.50 & 2.47 \\
ASF $(\mathrm{mm})$ & 12.29 & 6.02 & 21.80 & 6.08 \\
ICSF $(\mathrm{mm})$ & 8.41 & 3.22 & 14.35 & 4.82 \\
\hline
\end{tabular}

With respect to waist circumference, 201 $(91.7 \%)$ students were classified as normal and $18(8.3 \%)$ as obese. For waist-hip ratio, $82(37.4 \%)$ presented low scores, $81(36.9 \%)$ moderate and $56(25.7 \%)$ high. Regarding the classification of neck circumference, we observed that $20(9.2 \%)$ presented altered values.

We found that 201 (91.7\%) adolescents presented normal blood pressure values. Among the $18(8.3 \%)$ participants whose blood pressure values were outside of normality standards, $10(4.6 \%)$ belonged to the borderline category, $5(2.4 \%)$ were stage 1 hypertensive and $3(1.3 \%)$, stage 2 hypertensive.

Table 2 displays the correlations of anthropometric variables according to sex. The data indicate that male adolescents obtained higher mean values for SBP and DBP and weight, WC and NC variables. Among female participants, $\mathrm{BAI}$ and all skinfolds presented higher values with respect to males. Regarding items HC, WHR and WSR, mean values were approximate.
Table 2 - Pearson's correlation coefficient (r) between anthropometric measurements and SBP and DBP values among adolescents, according to sex. Imperatriz, Maranhão, Brazil, 2012 (n=218)

\begin{tabular}{lcc}
\hline Variables & SBP & DBP \\
\hline Male & & \\
Height $(\mathrm{m})$ & $0.34^{\ddagger}$ & $0.23^{\dagger}$ \\
Weight $(\mathrm{kg})$ & $0.52^{\ddagger}$ & $0.40^{\ddagger}$ \\
BAI & $-0.32^{\ddagger}$ & $-0.15^{*}$ \\
WC (cm) & $0.39^{\ddagger}$ & $0.28^{\ddagger}$ \\
HC $(\mathrm{cm})$ & $0.43^{\ddagger}$ & $0.40^{\ddagger}$ \\
WHR & $-0.00^{*}$ & $-0.15^{*}$ \\
Female & & \\
Height (m) & $0.18^{\dagger}$ & $0.24^{\ddagger}$ \\
Weight (kg) & $0.20^{\dagger}$ & $0.13^{*}$ \\
BAI & $-0.08^{*}$ & $-0.18^{\dagger}$ \\
WC (cm) & $0.17^{\dagger}$ & $0.14^{*}$ \\
HC (cm) & $0.16^{*}$ & $0.10^{*}$ \\
WHR & $-0.06^{*}$ & $0.08^{*}$ \\
\hline "Statistically non-significant; ${ }^{\dagger}$ 5\% level of statistical significance; \\
${ }^{\ddagger}$ 1\% level of statistical significance. &
\end{tabular}


Table 2 presents the variables with normal distribution and their correlation with SBP and DBP values according to sex. We found that, among the male adolescents, the only items that did not display significant correlation were WHR and BAI with DBP, as well as WSR with SBP. Furthermore, these participants' SBP demonstrated an inverse relation with BAI ( $\mathrm{r}=-0.32)$. We found the opposite result when investigating weight, which displayed a proportional and median relationship with SBP. Among female adolescents, there was a positive correlation between SBP with height, weight and WC. For DBP, the only significant variable was weight. However, despite the significant correlations presented, none were considered strong, since the positive and negative coefficients fell between 0.30 and 0.70 .

Table 3 displays the variables with non-normal distribution and their correlation to SBP and DBP values according to sex. Neck circumference (NC) presents direct and statistically significant correlation with DBP in both sexes. Furthermore, the DBP of male adolescents presented correlation with WSR and TSF, while SBP presented the same result with ICSF. The only anthropometric measurement that presented simultaneous correlation with SBP for both sexes was NC and WC.

Table 3 - Spearman's correlation coefficient $\left(r_{s}\right)$ between anthropometric measurements and SBP and DBP values among adolescents, according to sex. Imperatriz, Maranhão, Brazil, $2012(n=218)$

\begin{tabular}{lll}
\hline Variables & SBP & DBP \\
\hline Male & & \\
WSR & $0.20^{*}$ & $0.22^{\ddagger}$ \\
NC $(\mathrm{cm})$ & $0.41^{\ddagger}$ & $0.31^{\ddagger}$ \\
TSF $(\mathrm{mm})$ & $0.16^{*}$ & $0.23^{\ddagger}$ \\
BSF $(\mathrm{mm})$ & $0.02^{*}$ & $0.13^{*}$ \\
CSF $(\mathrm{mm})$ & $0.06^{*}$ & $0.10^{*}$ \\
ASF $(\mathrm{mm})$ & $0.16^{*}$ & $0.19^{*}$ \\
ICSF $(\mathrm{mm})$ & $0.21^{\dagger}$ & $0.18^{*}$ \\
Female & & \\
WSR & $0.08^{*}$ & $0.00^{*}$ \\
NC $(\mathrm{cm})$ & $0.16^{*}$ & $0.04^{\dagger}$ \\
TSF $(\mathrm{mm})$ & $0.10^{*}$ & $0.02^{*}$ \\
BSF (mm) & $0.07^{*}$ & $-0.09^{*}$ \\
CSF (mm) & $0.00^{*}$ & $0.04^{*}$ \\
ASF $(\mathrm{mm})$ & $0.08^{*}$ & $0.03^{*}$ \\
ICSF $(\mathrm{mm})$ & $0.09^{*}$ & $-0.01^{*}$ \\
\hline S
\end{tabular}

"Statistically non-significant; ${ }^{\dagger} 5 \%$ level of statistical significance;

${ }^{\ddagger} 1 \%$ level of statistical significance.

\section{DISCUSSION}

Approximately $8 \%$ of our adolescent sample had high blood pressure. This result is lower than that of other studies conducted in Brazil, which detected $11.8 \%$ and $52.4 \%$ percentiles for this juvenile health problem. ${ }^{2,19-21}$ However, a recent systematic review concluded that the prevalence of HBP among children and adolescents could encompass values between 3 and $20 \%$ at a global level. Furthermore, this divergence can also be justified because percentages can vary according to the method and number of measurements, as well as to diagnostic criteria. ${ }^{6}$

The protocol for classifying blood pressure in this article was the same as that in the abovementioned articles, specific for children and adolescents. However, the present analysis was based on one measurement obtained through the oscillometric method. Other authors emphasize that SBP and DBP assessments throughout time and the use of the auscultatory method lead to the detection of lower blood pressure levels. ${ }^{4,6}$ Thus, we conjecture that a longitudinal replication of this study could detect values lower than those found at the moment. This fact reinforces the permanent need for monitoring adolescent's blood pressure in the school setting.

Another result found in this study was the predominance of more elevated SBP and DBP values among male adolescents. This data confirms the findings made by other similar studies, ${ }^{10,12,22}$ in which the prevalence of HBP among males ranged from $10.2 \%$ to $52 \%$. Nonetheless, some authors have not identified any association between blood pressure and sex in adolescents. ${ }^{22-23}$ This result may be related to the fact that up to 12 years of age, both SBP and DBP do not diverge according to sex. It is only in adolescence that this situation inverts itself and there is a male supremacy regarding higher blood pressure values. ${ }^{24}$

In the present investigation, the only anthropometric measurements that presented correlation with SBP in both sexes were NC and WC. In contrast with this result, a longitudinal study conducted with Brazilian children and adolescents found significant correlation between hypertension and NC, subscapular skinfold and ICSF. ${ }^{23}$ Other publications, also conducted with adolescents, identified statistically significant associations between TSF and SBP, ${ }^{2} \mathrm{SBP} / \mathrm{DPB}$ with $\mathrm{WC}$ and $\mathrm{HC},{ }^{20}$ high blood pressure and $\mathrm{WC}^{24}$ high blood pressure and abdominal body fat, high blood pressure and TSF and BMI. ${ }^{25}$ 
We analyzed similar studies that found that the BMI, WC, WSR and conicity index are better anthropometric indicators for predicting prehypertension and hypertension in adolescents and adults. ${ }^{5,9}$ When presenting an anthropometric classification that indicates excess weight, the adolescent's chance for having high blood pressure is 3.1 times higher. ${ }^{20}$ The literature also indicates that there is a $10 \mathrm{mmHg}$ and $4 \mathrm{mmHg}$ increase in SBP and DBP, respectively, with respect to values expected for age and sex in overweight adolescents. ${ }^{24}$

In the present study, WC demonstrated a strong relation with the adolescent's blood pressure, a fact similar to that presented in other consulted studies. ${ }^{22-23}$ This fact intensifies the role of abdominal fat concentration as a predictor for developing $\mathrm{HBP}$ in adolescents. In opposition to the previously mentioned studies, we did not find any significance between these two variables, which raises the hypothesis that the cutoff points for WC classification may have distorted the estimates for high blood pressure risk in these studies. In fact, authors have criticized the use of cutoff points for all ethnicities, for this variable is not sufficiently specific for detecting HBP levels in Brazilian children and adolescents, which is possibly due to the strong miscegenation that defines the Brazilian population and that requires specific values. ${ }^{22-25}$

Concerning neck circumference, male adolescents presented higher mean values of adiposity and a direct and statistically significant correlation with DBP in both sexes.

We found only one citation in the literature regarding the association between $\mathrm{NC}$ and blood pressure in adolescents. In this case, there was a statistically significant association between NC and dyslipidemia ${ }^{13}$ among adults, and Brazilian studies that found an association or statistically significant correlation between hypertension and SBP/DBP, respectively. ${ }^{17,26}$ We also found publications from Europe and the United States whose results demonstrated a positive correlation between SBP/DBP and neck circumference..$^{27-29}$

Despite the scarcity of bibliographic studies on the topic, we consulted some manuscripts that were unanimous in stating the following conclusion: NC is a measurement capable of predicting alterations in body fat and metabolism. 11,13,27-29 Therefore, it can serve as an important practical instrument for predicting blood pressure and cardiovascular risk, for most frequently, hypertension can by asssyptomatic. ${ }^{30}$

\section{CONCLUSION}

Anthropometric evaluation is a simple, effective and low-cost measure that can contribute to deal with high blood pressure, for anthropometric indicators can provide indications of body fat accumulation and consequently, of disorders correlated with elevated SBP and DBP, blood glucose and triglyceride levels. In light of this observation, we consider it a priority to encourage early detection and weight reduction, for even small losses can result in significant decreases in blood pressure in the juvenile population.

Despite the fact that a small portion of the sample presented high blood pressure, the values for SBP and DBP indicated significant correlations with some anthropometric measurements, especially WC and NC. Another important issue is the need for nurses to increase their presence in the school setting in order to monitor risk factors for noncommunicable chronic diseases. This situation can take place through health education actions that promote a healthy lifestyle since childhood and/or adolescence. Another important, practical and economically viable measurement is the analysis of anthropometric data, for with this instrument, school nurses can help promote the health of children and adolescents.

As a limitation of our study, we mention the fact that we based our blood pressure analysis on one single evaluation (cross-sectional analysis) and with a reduced sample. Therefore, causal relations may not have been established. Furthermore, we emphasize that we did not evaluate other cardiovascular risk indicators, such as glucose tolerance and body fat composition. These are very important items for evaluating the risk related to hypertension in children and adolescents. In light of these methodological limitations, we recommend that the results presented in this study be used with caution. We also suggest that this study be replicated in other clinical scenarios with an improved methodological design.

\section{REFERENCES}

1. Sociedade Brasileira de Cardiologia, Sociedade Brasileira de Hipertensão, Sociedade Brasileira de Nefrologia, IV Diretrizes Brasileiras de Hipertensão Arterial. Rev Bras Hipertens. 2010 Dez; 95(supl.1): 1-51.

2. Araújo TL, Lopes MVO, Cavalcante TF, Guedes NG, Moreira FP, Chaves ES, et al. Análise de indicadores de risco para hipertensão arterial em crianças e adolescentes. Rev Esc Enferm USP. 2008 Jan-Mar; 42(1):120-6. 
3. Abreu S, Santos R, Moreira C, Santos PC, Mota J, Moreira P. Food consumption, physical activity and socio-economic status related to BMI, waist circumference and waist-to-height ratio in adolescents. Public Health Nutr. 2013 Jul; 22 (Suppl 1): S1-16.

4. Fonseca FL, Brandão AA, Pozzan R, Campana EMG, Pizzi OL, Magalhães MEC, et al. Relação entre a pressão arterial e índices antropométricos na infância/adolescência e o comportamento das variáveis de risco cardiovascular na fase adulta jovem, em seguimento de 17 anos: estudo do Rio de Janeiro. Rev SOCERJ. 2008 Set-Out; 21(5):281-90.

5. Campana EMG, Brandão AA, Magalhães MEC, Freitas EV, Brandão RPAP. Pré-hipertensão em crianças e adolescentes. Rev Bras Hipertens. 2009 Abr-Jun; 16(2):92-102.

6. Thompson M, Dana T, Bougatsos C, Blazina I, Norris SL. Screening for hypertension in children and adolescents to prevent cardiovascular disease. Pediatrics. 2013 Mar; 131(3):490-525.

7. Chiolero A, Bovet P, Paradis G. Screening for elevated blood pressure in children and adolescents: a critical appraisal. JAMA Pediatr. 2013 Mar; 167(3):266-73.

8. Dhuper S, Buddhe S, Patel S. Managing cardiovascular risk in overweight children and adolescents. Pediatr Drugs. 2013 Jun; 15(3):181-90.

9. Beck CC, Pitanga AS, Gondim FJ. Anthropometric indicators as predictors of high blood pressure in adolescents. Arq Bras Cardiol. 2011 Nov; 96(2):126-30.

10. Oliveira MMA, Fagundes RLM, Moreira EAM, Trindade EBSM, Carvalho T. Relation between anthropometric indicators and risk factors for cardiovascular disease. Arq Bras Cardiol. 2010 Apr; 94(4):478-85.

11. Moser DC, Giulliano Ide C, Titski AC, Gaya AR, Silva MJC, Leite N. Anthropometric measures and blood pressure in school children. Pediatrics. 2013 May-Jun; 88(3):243-9.

12. Silva KS, Júnior JCF. Risk factors associated with high blood pressure in adolescents. Rev Bras Med Esporte. 2007 Jul-Ago; 13(4):213-6.

13. Polit DF, Beck CT. Fundamentos de pesquisa em Enfermagem: avaliação de evidências para a prática de enfermagem. $7^{\text {a }}$ ed. São Paulo (SP): Artmed; 2011.

14. Organización Panamericana de la Salud. Promoción de la salud en las Americas. Washington (US): OPS; 1993.

15. Gonçalves VSS, Faria ER, Morais DC, Franceschini SCC, Priore SE. Perímetro do pescoço como preditor de excesso de gordura corporal no início da adolescência. In: Anais do XXII Congresso Brasileiro de Nutrição, 2012 Set 26-29, Olinda, Brasil. Olinda (PE): Vision Eventos; 2012.

16. Duarte ACG, Castellani FR. Semiologia Nutricional. Rio de Janeiro (RJ): Axcel; 2002.
17. Taylor RW, Jones IE, Williams SM, Goulding A. Evaluation of waist circumference, waist-to-hip ratio, and the conicity index as screening tools for high trunk fat mass, as measured by dual-energy X-ray absorptiometry, in children aged 3-19 y. Am J Clin Nutr. 2000 Aug; 72(2):490-5.

18. Smith C, Essop MF. Gender differences in metabolic risk factor prevalence in a South African student population. Cardiovasc J Afr. 2009 May-Jun; 20(3):178-82.

19. Pereira DCR. Análise da circunferência do pescoço como marcador para síndrome metabólica em estudantes de uma universidade pública em Fortaleza-CE [dissertação]. Fortaleza (CE): Universidade Federal do Ceará, Programa de PósGraduação em Enfermagem; 2012.

20. Canadian Standardized Test of Fitness (CSTF). Operations Manual. $3^{\mathrm{a}}$ ed. Ottawa (CA): Government of Canada, Fitness and Amateur Sport; 1986.

21. Pinto SL, Silva RCR, Priore SE, Assis AMO, Pinto LJ. Prevalência de pré-hipertensão e de hipertensão arterial e avaliação de fatores associados em crianças e adolescentes de escolas públicas de Salvador, Bahia, Brasil. Cad Saúde Pública. 2011 Jun; 27(6):1065-76.

22. Christófaro DGD, Casonatto J, Fernandes RA, Mathias FF, Lock MR, Guariglia DA, et al. Pressão arterial elevada em adolescentes de alto nível econômico. Rev Paul Pediatr. 2010 Mar; 28(1):23-8.

23. Silva PCV, Araújo MFM, Almeida LS, Vasconcelos HCA, Freitas RWJF, Damasceno MMC, Lopes MVO. Blood pressure of adolescents in private schools in Fortaleza-CE. Acta Paul Enferm. 2010 Oct; 23(4):512-8.

24. Araújo TL, Lopes MVO, Cavalcante TF, Guedes NG, Moreira FP, Chaves ES, et al. Relación entre medidas antropométricas y valores de la presión arterial en estudiantes brasileños. ALAN [online]. 2006 [acesso 2012 Abr 14]; 56(3). Disponível em: http:// www.scielo.org.ve/ scielo.php?pid=S000406222006000300002\&script $=$ sci_arttext

25. Clemente APG, Santos CD, Silva AAB, Martins VJ, Marchesano AC, Fernandes MB, et al. Mild stunting is associated with higher blood pressure in overweight adolescents. Arq Bras Cardiol. 2012 Jan; 98(1):6-12.

26. Rosa MLG, Mesquita ET, Rocha ERR, Fonseca VM. Body mass index and waist circumference as markers of arterial hypertension in adolescents. Arq Bras Cardiol. 2007 May; 88(5):573-8.

27. Souza MGB, Rivera IR, Silva MAM, Carvalho ACC. Relationship of obesity with high blood pressure in children and adolescents Arq Bras Cardiol. 2010 Apr; 94(6):714-9.

28. Tibana RA, Teixeira TG, Farias DL, Silva AO, Madrid B, Vieira A, et al. Relação da circunferência do pescoço com a força muscular relativa e os fatores 
de risco cardiovascular em mulheres sedentárias. Einstein. 2012 Jul-Sep; 10(3):329-4.

29. Sjöström CD, Hakangard AC, Lissner L, Sjöström L. Body compartment and subcutaneous adipose tissue distribution - risk factor patterns in obese subjects. Obes Res. 1995 Jan; 3(1):9-22.

30. Vallianou NG, Evangelopoulos AA, Bountziouka V, Vogiatzakis ED, Bonou MS, Barbetseas J, et al. Neck circumference is correlated with triglycerides and inversely related with HDL cholesterol beyond BMI and waist circumference. Diabetes Metab Res Rev. 2013 Jan; 29(1):90-7.
31. Preis SR, Massaro JM, Hoffmann U, D'Agostino RBS, Levy D, Robins SJ, et al. Neck circumference as a novel measure of cardiometabolic risk: the Framingham heart study. J Clin Endocrinol Metab. 2010 Aug; 95(8):3701-10.

32. Silva FM, Budó MLD, Silveira CL, Badke MR, Beuter M. Hypertension as a condition of nondisease - the meaning of chronicity in the subjects' perspective. Texto Contexto Enferm. 2013 Mar [acesso 04 Abr 2014]; 22(1):123-31. Disponível em: http:// www.scielo.br/scielo.php?pid=S010407072013000100015\&script=sci_arttext 